\title{
Breasts, Bags, Clothes and Shoes: Constructing Motherhood and Images of Breastfeeding vs. Formula Feeding Women
}

\author{
Emma Mohamad \\ School of Media and Communication, Faculty of Social Sciences and Humanities \\ Universiti Kebangsaan Malaysia, Malaysia \\ E-mail:mirza@ukm.my,dr.emma.mohamad@gmail.com
}

Received: February 28, 2012

Accepted: March 13, 2012 Published: April 16, 2012

doi:10.5539/ass.v8n5p93

URL: http://dx.doi.org/10.5539/ass.v8n5p93

This project is part of author's PhD research funded by the Ministry of Higher Learning Malaysia under the Bumiputera Academic Training Scheme.

\begin{abstract}
Breastfeding does not only take place in women's bodies but it helps construct the notion of 'good' and 'bad' mothers (Kukla, 2006a). According to Kukla, our idea of the maternal body (including breastfeeding) is contextualised by the surrounding discourses which dominate and constrain our definition and the meaning of maternality. Discourses around infant feeding also tend to repackage our definition of what motherhood is, and certain expectations that it brings. This paper discusses the construction of motherhood and images of "good" vs. "bad" mothers through collages. It explores women's negotiations with the types of bodies and values attached to both infant feeding choices. This data is generated through women's responses in focus groups and having them constructing collages of breast and formula feeding mothers. Through these processes, women discussed values associated with the types of women who would breast or formula feed, as well as other moral issues associated with motherhood.
\end{abstract}

Keywords: Breastfeeding, Creative visual methods, Motherhood

\section{Introduction}

This paper discusses ideas surrounding 'types' of women who would breast or formula feed. It explores women's negotiations with types of bodies and values attached to motherhood. This is generated through women's construction of collages; both breast and formula feeding mothers. Through these collages, women discuss values associated with the types of women who would breast or formula feed, their identities, as well as other moral issues associated with motherhood.

\section{The conceptions of motherhood}

Breastfeeding does not only take place in women's bodies, but it helps construct the notion of 'good' and 'bad' mothers (Kukla 2006a). According to Kukla, our idea of the maternal body (including breastfeeding) is contextualised by the surrounding discourses which dominate and constrain our definition and the meaning of maternality. Discourses around infant feeding also tend to repackage our definition of what motherhood is, and certain expectations that it brings. These expectations include responsibilities towards children's health and upbringing; a duty that has now been conferred a civic value as much as its' domestic significance (Kukla 2006b p.164). The context of infant feeding choice is no longer seen as one's rights, but a moralised and constrained one that tends to label individuals' moral state as either 'good' or 'bad' mothers.

Elizabeth Murphy in 2000 wrote about risk discourses of infant feeding and explains how such discourses help construct moral aspects of motherhood. In her research she found out that mothers tend to blame others (including their own babies) and external circumstances for their failure to breastfeed. This is because of the pressures put upon them to become, and to be seen as 'a good mother'. Murphy suggests that the way mothers talk about their decision to formula feed "endorsed the ideology of motherhood, resisting any interpretation of their feeding practices that suggest that they had failed to live up to this ideology" (Murphy, 2000 p.319). 
For example, a study by Mabilia (2005) explores how breastfeeding practices are defined through specific cultural beliefs that shape social interpretations of motherhood. Mabilia explained that the Gogo community in Tanzania forbids lactating mothers from having sexual intercourse during the course of breastfeeding. This is because the society believes that having sexual intercourse will affect mothers' milk, causing their babies to be ill. Interestingly, because of this belief, mothers who have ill babies are deemed as "bad mothers" because they are thought to prioritise sex over the health of their own babies (p.67). This is an interesting process in which cultural beliefs and taboos related to breastfeeding affect the social definition of "good" and "bad" mothers.

Maclean (1990) also suggests that breastfeeding serves as society's measure stick for defining a good or bad mother (p.52). The power of such discourse lay not so much in enforcing women to breastfeed, but in shaping the moral context in which the infant feeding decision is treated, reflecting the maternal identity.

Joyce Marshall and Mary Godfrey (2011) who conducted a study with mothers in the UK suggest that although public health discourse often associates breastfeeding with "good mothering", it competes with other normative values of a good mother held by individuals or society in which women surround herself with. This is an example of the myriad social influences that may affect how women perceive breastfeeding and motherhood, as well as how they relate to their infant feeding experiences.

Social discourses surrounding issues of breastfeeding today and risks associated with formula feeding operate a moral directive for "good mothering" (Murphy 2000, p.295). The notion of choice has become "more directly tied to notions of success and failure [as a mother]" (Knaak 2005, p.212). This context of choice has changed over time which may also have affected breastfeeding trend. An inquiry into the problem of "choice" should take into consideration both the inner body experience as well as the external institutions. It is therefore crucial to explore mothers' experiences and examine dominant discourses of infant feeding in order to understand how the contextualisation of mothers' decision making operates. This paper attempts to explore this.

\section{Research Method}

Each focus group was divided into two smaller groups and mothers were asked to create a collage of a breastfeeding woman and a formula feeding woman. To accomplish this, the groups were provided with three local magazines (The June 2009 issue of Keluarga and May 2009 issue of both Harmoni and Wanita) and two international magazines (The May 2009 issue of New Weekly and April 2009 issue of OK!). Research participants were also given scissors, glue and art paper. They were asked to choose and cut out pictures/body parts from the magazines and construct a complete collage of (a) A breastfeeding woman and (b) A formula feeding woman. After completing their task, each group was then given the opportunity to present their collages and discuss with the whole group about their project.

The objective of this exercise was to observe participants' interpretations of both infant feeding styles, conveyed through their choices of characters, body parts and values attached to both breast and formula feeding women. Below is the distribution of focus group respondents and some background of the groups

$<$ Insert Table 1 Here>

\subsection{Why Collages?: Engaging audiences with creativity}

Visual exercises and prompts stimulate the brain in a different way. As Gauntlett (2004) notes,

"When visualising a concept or a problem, we might picture a number of things at once, and perhaps see them as interconnected, but language forces us to put these into an order, one first and then the others, with the former often seeming to act upon or influence the latter" (p.12).

Gauntlett points out that media studies so far have only treated people as audience of particular text, forms or genre, often isolating other media sources and people's lived experience. Gauntlet (2004) argues that people are exposed to different media sources which constitute a significant part of their experience and understanding (p.3). Gauntlet's approach explores audience relationship with the media through creative visual methods, in which he claims to have helped overcome the limitations of language based methods in previous studies. He argues that visual materials are non-linear and therefore, research participants are not focused on giving the "right answers" but are engaged in different cognitive processes that will produce different perspectives on the issues discussed. He explains that creative methods allow participants to interpret materials given to them, a formula which invites them to be part of a creative process. This will generate different sets of findings inspired by the participants themselves as opposed to confining them to a predetermined structure.

However, creative exercises can be a complicated method and subjective in nature. Therefore, there is a possibility that the collages may only represent women constructing stereotypes. Nonetheless, the collages also 
demonstrated that these stereotypical opinions are embedded in the way women perceived the types of mothers who would or would not breastfeed. It also suggested that women shared similar opinions when constructing these images. This may then relate to for example, the process of reinforcing/rejecting/negotiating certain ideas about motherhood.

\subsection{Collages: Constructing breastfeeding and formula feeding mothers}

In this section, we will discuss the collages and mothers' discussions about the types of mothers who would or would not breastfeed. In the collage exercise, we asked mothers to generate two collages (a breastfeeding and a formula feeding woman) based on their subjective interpretation. These collages are considered both as products and processes by which mothers negotiate breastfeeding and formula feeding bodies. This is defined through both physical and psychological attributes of the collages such as the clothing, hairstyles and accessories, among other things. Mothers were also given the opportunity to explain their choices and rationales for their selection of pictures in their collages at the end of the exercise.

The exercise combines both language based method through mothers' collage presentations and the creative method of constructing the collages itself. This dual approach enabled mothers to take time to negotiate with each other and decide as a group how they would construct their images. They also have the chance to think about what they would like to include in their collages and later have the chance to explain about their project. On some occasions, mothers had the chance to reflect on their decisions and choices of pictures used in their collages.

However, in this exercise mothers were able to produce and convey different values towards breastfeeding and formula feeding mothers (both positive and negative) through their collages without directly upsetting anyone in particular. This was an advantage of this method. The collage exercise has helped alleviate some tensions (if any) between breastfeeding and formula feeding mothers. Those who avoided commenting on infant feeding choices were more outspoken in their responses in the collages. Participants felt that the collages represent a non-real person and thus they felt more at ease commenting on these collages and their values according to infant feeding choices. Also the constructions of these collages represent ideologies of motherhood and symbolise how society defines 'good' and 'bad' mothers. It was notable through the collages that infant feeding choice was a measure stick used to socially define motherhood and qualities of a good mother.

Many of the groups tried hard to separate values between their two collages. It was observed that there was an overall distinction between breastfeeding and formula feeding collages across all groups. For example, research participants conveyed the idea of "healthy lifestyle" for breastfeeding mothers and "unhealthy choice" for formula feeding mothers through their choice of body parts (see figure 1).

$<$ Insert Figure 1 Here $>$

In the focus group it was mentioned that the overall idea of their collage was to show that breastfeeding is a healthy choice for mothers. Maria explained,

"Breastfeeding is a healthy way of life. Mothers who breastfeed would usually eat healthy food, takes care of herself and makes sure she provides the best for her baby. Formula feeding mothers on the other hand would usually lead an unhealthy life. Like this anorexic woman (referring to her formula feeding collage) (29, BF, Focus Group 7, City).

In another group, mothers used Malay traditional costumes to construct breastfeeding collage, while their formula feeding collage showed a picture of woman in modern western outfit (refer figure 2). The collages illustrated the difference between traditional and modern look through the choice of outfit.

$<$ Insert Figure 2 Here $>$

Our overall analysis also suggests some similar qualities attached to the breastfeeding/formula feeding collages across all groups. Although this may be just a sign of stereotyping but it also showed that the process of identity construction and values attached to these collages has little connection with their own experiences with infant feeding. As one mother reflected after presenting her collages, "Come to think of it, there is no way for anyone to know whether a mother breastfeeds or not just by looking at her appearance," (Rania, 29, Focus Group 1, City).

It was observed that the way mothers understand the types of women associated with breastfeeding or formula feeding is influenced by other factors and not by themselves. This attached values then contributes to their understanding of larger issues for example the idea of 'good mothers' and 'less good mothers'. As we recalled the focus group participants, it did occurred to us that most of them wore similar type of clothes. None of them 
(especially the formula feeding mothers) wore sexy, tight-fitting clothes or carried small bags the way that they have pictured in their collages. We will try to explore this and the cross similarities of values that research participants attached to their breastfeeding (or formula feeding) collages next.

\subsection{Bodies, bags, clothes and shoes}

Throughout all the collages, we observed four striking opposite values between the breastfeeding and formula feeding collages across all groups. It was amazing that almost all groups were consistent with their choice of body types, bags, clothes and shoes for their breastfeeding and formula feeding collages. Additionally, it was also observed that all groups used similar colours and facial expressions to construct breastfeeding or formula feeding women. These attributes carry specific meanings, individually and contribute to the overall look for breastfeeding and formula feeding mothers. These attached meanings were later reinforced in mothers' presentations.

\section{$<$ Insert Figure 3 Here $>$}

In most breastfeeding collages, women were shown with large bags and flat shoes (refer to figure 3). In contrast to this, formula feeding collages often portrayed women in high heels and smaller bags (refer to figure 4). As mothers explained their breastfeeding collages, they mentioned big bags for carrying nappies and baby needs. Flat shoes on the other hand were mentioned to provide mothers with comfort and stability while holding their babies. Rania for example explained this,

"Breastfeeding mothers would always wear flat shoes and carry large handbags so it would be easier for them to carry all her baby's necessities when she goes out. She needs to be prepared at all times you know, so she keeps things simple and casual, but yet stylish in her own way."

\section{(29, BF, Focus Group 1, City)}

The way Rania and other research participants described large bags represents qualities of a "good mother" as she would prioritise the needs of her baby more than her own. However, one can actually argue that breastfeeding mothers do not need to carry large bags because she doesn't have to bring baby bottles and feeding supplies. Nonetheless, overall formula feeding collages seemed to suggest the opposite, as readers will see in the examples next (figure 4):

\section{$<$ Insert Figure 4 Here $>$}

While presenting the formula feeding collages, women suggest that small bags and high heels represent modern lifestyle. Often times, research participants also described formula feeding mothers as selfish to prioritise fashion over their babies' needs. As one mother Qaseh explained,

"Formula feeding women would usually wear stilettos or very high heels. They are not suitable when you have to carry a child. She won't be able to keep her balance. Its a bit tricky, you know.. to cling on the clutch and carry her baby at the same time. Breastfeeding mom wouldn't carry a clutch. Bigger bags are more suitable for them."

\section{(29 BF, Focus Group 1, City)}

It was also observed that formula feeding collages often showed women inclined towards the thinner looking bodies and often dressed in vibrant colours, tight-fitting or revealing outfits. Research participants seemed to relate formula feeding mothers with "sexy bodies" (Group 8 - Focus Group 4, Town), which suggests a more sexually-appealing figure. Some other the words used to describe this sexual appeal are: "tight fitting" (Group 2 FG1, Group 2 FG3, Group 1 FG9), "showing off her legs" (Group 1 FG2), (Group 1 FG4), "wears stilettos" (Group 1, FG5) and "lets her hair down" (Group 1, FG5). This can also be observed for example in the formula feeding collages next (Figure 5):

\section{$<$ Insert Figure 5 Here>}

Overall the formula feeding collages represented mothers as bold, professional, stylish and thin. The collages also illustrated different ways breastfeeding and formula feeding bodies are represented in public space. For example, some outfit put together for the formula feeding collages are more revealing compared to the breastfeeding collages (which tend to be covered, modest and some looking "homely").

Breastfeeding outfits among other things was described as "comfortable and loose" (Group 2 FG1 and Group 2 FG3), "motherly" (Group 2 FG1, Group 1 FG4, Group 2 FG5 and Group 2 FG6) "stylish but not sexy" (Group 2 FG2), "casual' (Group 2 FG5) and "modest and demure" (Group 1 FG9). 
It was noticeable that breastfeeding bodies overall signified values such as soft, natural, feminine, healthy, happy and serene. This was illustrated through the outfit styles, facial expressions and the tone of colours in general. It was also interesting that four groups decided to use pregnant bodies for their breastfeeding collages (see figure 6). However, none of the four groups mentioned anything about the pregnant bodies in their presentations. They however, mentioned bodily gestures in the overall look for example, "the hand on the tummy" (Group 2, Focus Group 6) or "she is looking at her belly" (Group 2, Focus Group 5) and "looking all motherly" (Group 2, Focus Group 5) suggesting the amount of love and care these mothers have towards their babies. Again, research participants seemed to attach values to suggest breastfeeding mothers as "good mothers" who prioritise their babies' wellbeing before their own, while formula feeding mothers often depicted as selfish and therefore "less good mothers".

$<$ Insert Figure 6 Here $>$

On rare occasions similar attributes were seen in both breastfeeding and formula feeding collages. However, these attributes often suggested opposite values and contrasted meanings. For example, on occasions where breastfeeding collages were portrayed with big breasts, the meanings attached to them are associated with milk engorgement (motherly). In contrast, when mothers explained their choice for portraying big breasts on formula feeding collages, they would associate them with sexual connotations. For example, when explaining her group's breastfeeding collage (refer figure 7) Mila said,

"It is obvious that you can tell from her breasts that this woman breastfeeds. She has big breasts that are engorged with milk. Her chest area is revealed because it would be easier for her to breastfeed."

$$
\text { (29, FF, Group 1, Focus Group 1, City) }
$$

In another focus group, an image of full breasts on a breastfeeding body was again associated with milk engorgement. "She's not too sexy. Her breasts... there is a lot of milk in there," said Dina (34, BF, Group 1 FG2, City).

In contrast, formula feeding collages portrayed with big breasts were described as sexual. Latifah demonstrated this when she explained her group collage (refer to the second picture in figure 7), "Her breasts are firm and nice. Her husband must have really liked them very much" (28, FF, Group 2, Focus Group 8, City).

$<$ Insert Figure 7 Here $>$

Similarly, when describing her group's formula feeding collage, Acha associated big breasts with sexual appeal and selfishness. She explained, "This woman loves her big breasts. She wouldn't want to breastfeed because she doesn't want her breasts to sag” (26, BF, Group 1, Focus Group 4, Town).

Surprisingly, this "selfishness" manner was even mentioned by one formula feeding mother:

"We all know that this woman wouldn't want to breastfeed her baby. She cares too much of her appearance. She wouldn't let her children ruin them. As for her face expression, she looks uptight... like a stern and easily irritated mom. She is just so un-motherly in so many levels, and that is why she would formula feed her kids."

\section{(Mila, 29, Group 1, Focus Group 1, City)}

Furthermore, eight collages of breastfeeding women used Malay/local faces as opposed to four in formula feeding collages. We also found it interesting how none of the groups chose images of women wearing hijab for their formula feeding collages, whereas three groups used pictures of women wearing hijab for their breastfeeding collages (for example, refer figure 8 below).

$<$ Insert Figure 8 Here $>$

Although it was not mentioned in any of the presentations, this difference could suggest that breastfeeding is more associated with Malay mothers and Islamic culture, albeit mostly hidden from the media and public space. Furthermore, the significance of hijab in these collages may also suggest other values such as modesty and feminine, which can symbolise the expected behaviours and breastfeeding bodies in public locations. As Bunga explained, "We chose a hijabi woman for our breastfeeding collage because she is polite, fully covered and looks traditional" (24, MF, Focus Group 9, Rural).

In some breastfeeding collages, research participants also included pictures of babies. Although research participants did not use any baby pictures in their formula feeding collages, one group (Group 1, Focus Group 8) did include a slightly older child as part of their formula feeding collage. However, the way in which children are 
presented in the breastfeeding and formula feeding collages were different. In the breastfeeding collages, babies are often put near (or overlapping) the mother (refer figure 9).

$<$ Insert Figure 9 Here $>$

In contrasts, when a child is used in a formula feeding collage (refer figure 10) he is shown as a separate entity. In this particular collage, research participants also included a male adult (the only group to do so), which represents a father figure. The presence of a male figure suggests the significance of a father and that he plays an important role in the formula feeding family. The whole collage also symbolises a family with modern lifestyle. This was later reinforced in their presentation, along with other negative values associated with a formula feeding family. As one research participant explained,

"This mother is a fashion model. She doesn't have time to breastfeed her kids. Look at her outfit... how can you breastfeed wearing like this? This is the dad (pointing at the male collage). He's very macho and metrosexual. I don't think he supports breastfeeding. As for the little boy... just look at him. He's going to grow up to be just like one of those road bullies you know, those motorbike teenagers racing on the road."

(Lola, 41, FF, Focus Group 8, City)

$<$ Insert Figure 10 Here $>$

\section{Discussion}

Our analysis of the collages revealed that the identity of breastfeeding mothers (or formula feeding) are not fragmented. In contrast, the collages illustrated how different values are corroborated through carefully selected choice of images to project an overall image of motherhood and the types of mothers who would (or would not) breastfeed. All the groups constructed a complete image of woman for both collages and none of them use disjointed pictures, abstracts or written words to describe their project. It was also observed that every group constructed opposite values between breast and formula feeding collages, even when they could put together similar pictures. Interestingly, values associated with breastfeeding or formula feeding collages were coherent across all groups, despite mothers' diverse social backgrounds, locations, infant feeding styles and whether or not they consciously articulated this. Coherence across all groups was seen in the choice of shoes, clothes, bodies and bags as well as the choice of words they use to explain their collages.

The collages and associated discussions around them revealed that research participants have a clear image of the "type" of women who would breast or formula feed. Participants used different objects and body shapes to represent abstract concepts (such as "healthy", "modern", "selfish" or "feminine"), which are also associated with these types of women. We used detailed analysis to deconstruct these collages; at the same time, we also listened to the mothers' explanations of their selections and construction of both breastfeeding and formula feeding images.

The collages contained multiple meanings through the constructed visuals, which may be influenced by mothers' preconceived ideas about certain values and behaviours. The individual signifiers such as shoes, clothes, bags and bodies itself, represent the overall description and expectations of breast and formula feeding mothers which then contribute to a larger definition of motherhood. When research participants presented their collages, they relate their choices with mothering styles and behaviours. These choices of symbols also help deconstruct complex concepts such as lifestyle choices and human relationships. For example, the choice of clothes, shoes and bags can represent mothers' daily lives activities, as well as the relationship mothers have with their children. These then imply the different values and behaviours between mothers who chose to breastfeed and those who chose not to. Mothers who breastfeed are often associated with good mothering qualities and prioritise her baby. On the other hand, mothers who formula feed are seen selfish and less intimate with their children.

This creative process also revealed the complexity of infant feeding styles. It was observed that breastfeeding and formula feeding do not only represent food for babies, but are also implicated in other complex issues of motherhood and society. On several occasions, some research participants had moments of reflection and acknowledge that their collages were most probably as a result of them stereotyping. Some research participants pointed out that it was indeed impossible to identify one's infant feeding style just by looking at a mother's appearance. Nonetheless, this exercise has brought up some subconscious thoughts (even when it was just stereotypes) which influences the way they construct ideas about motherhood (by defining infant feeding styles, types of women and moral values attached to them). These subconscious thoughts are deeply embedded in each individual and may be as a result of social and cultural conditioning. 
The collages uncovered subjective characteristics associated with breastfeeding and formula feeding mothers which was not discussed in the focus groups. Some of these characteristics support earlier findings in focus groups such as the maternal and sexual meanings of breasts, while some others suggested different meanings altogether. More importantly, this exercise reinforced significant polarity between breastfeeding and formula feeding mothers, physically and morally.

For example, breastfeeding collages conveyed images of "good mothers" through the way they are dressed, which often to assist breastfeeding and therefore, puts the child's priority before hers. In contrast, formula feeding collages were styled in tight fitting clothes and fashionable outfits which to suggest her selfish decision to prioritise her desires before her babies' needs. Although these may just simply be stereotypes, the collages also help highlighted abstract moral codes and conduct. It also showed how infant feeding choice has become a social measure for becoming a "good mother" and contributes to the ideologies of motherhood.

The findings resonated with Kukla's idea of societal definition of "good" vs. "bad" mothers through their infant feeding choices. Indeed, it was clear from the collages that infant feeding choices help construct ideas of motherhood and social definition of "good" vs. "bad" mothers. In addition, this study has specifically pointed out how elements of women bodies and attires are used to signify and uphold this social definition. What was even more interesting was that this process of labeling women as "bad mothers" was done subconsciously, even when many of the respondents themselves were formula feeding mothers. This showed that the constructions of motherhood is deeply embeded and that respondents themselves did not seem to relate to their own situation / experiences with infant feeding. Arguably, formula feeding mothers could be "good" too if not as "equally good" as the breastfeeding mothers.

\section{Conclusion}

The collages and associated discussions around these collages revealed that research participants have a clear image of the "type" of women who would breast or formula feed. It was striking that although the collages showed great variation and subjectivity of interpretations, quite a number of similar objects/images were used to separate breastfeeding and formula feeding collages across all the focus groups: the big handbag, the high heels, the positioning of a father, pregnancy bodies etc. Oppositional values were also attached to both infant feeding styles in mothers' presentations of the collages (for example, traditional vs. modern and maternal vs. sexual). This somewhat interacts with the wider social understanding of motherhood and socio-cultural expectations that comes with both infant feeding styles.

The choice to breast or formula feed contributes to the conceptualisation of motherhood. The study concurred to Kukla's argument (2005) that infant feeding is used as a social measurement for defining a "good" (or "less good") mother. Breastfeeding is described as selflessly prioritising a baby's needs (and symbolised by for example, loose clothing to facilitate breastfeeding). Conversely, women explained that choosing to formula feed is selfish because a mother prioritises her needs before her baby's (and symbolised by for example, high heels and stylish tight fitting clothes). However, strikingly, the context of "good" or "less good" mothers (portrayed in the collages) do not seem to resonate participants" own identity, their infant feding choice, how they are dressed or how they see themselves as mothers. Symbols such as bags, clothing, shoes and types of bodies carries deeper ideas in the construction of motherhood however this may not necessarily translate the same in the context of reality nor can it be the measurements of good / bad mothers. Yet, it should be noted that although breastfeeding plays a role in the construction of motherhood and the ideas of "good" and "less good" mother at the society level, it also competes with individual normative values and opinions on "good mothering".

\section{References}

Ang, I. (1985). Watching Dallas: Soap Opera and the Melodramatic Imagination. London: Methuen.

Ang, I. (1991). Desperately Seeking the Audience. London: Routledge. http://dx.doi.org/10.4324/9780203321454

Ang, I. (1996). Living Room Wars: Rethinking Media Audiences for a Postmodern World. London: Routledge. http://dx.doi.org/10.4324/9780203289549

Dyer, G. (1982). Advertising as communication. London: Methuen. http://dx.doi.org/10.4324/9780203328132

Eldridge, J., Kitzinger, J. \& Williams, K. (1997). The mass media and power in modern Britain. Oxford: University Press.

Gauntlett, D. \& Hill, A. (1999). TV Living: Television, culture and everyday life. London: Routledge.

Gauntlett, D. (1997). Video critical: Children, the environment and media power. London: John Libbey. 
Gauntlett, D. (2002). Media, gender and identity: An introduction. London: Routledge. http://dx.doi.org/10.4324/9780203360798

Gauntlett, D. (2004). Using new creative visual research methods to understand the place of popular media in people's lives. Paper presented at the International Association for Media and Communication Research $(I A M C R)$. Porto Alegre, Brazil.

Gauntlett, D. (2007). Creative explorations: New approaches to identities and audiences. London: Routledge.

Henderson, L. (2007). Social issues in television fiction. Edinburgh: University Press.

Kitzinger, J. (1990). Audience understandings of AIDS media messages: A discussion of methods Sociology of Health and Illness, 12(3), pp. 319-335. http://dx.doi.org/10.1111/1467-9566.ep11347258

Kitzinger, J. (1993). Understanding AIDS: Researching audience perceptions of acquired immune deficiency syndrome. In Eldridge, J. (ed). Getting the message: News, truth and power. London: Routledge. http://dx.doi.org/10.4324/9780203397404_chapter_11

Knaak, S. (2005). Breast-feeding, bottle-feeding and Dr. Spock: The shifting context of choice. The Canadian Review of Sociology and Anthropology, 42(2), pp. 197-216. http://dx.doi.org/10.1111/j.1755-618X.2005.tb02461.x

Kukla, R. (2006a). Introduction: Maternal Bodies. Hypatia 21(1), pp. vii-ix. http://dx.doi.org/10.1111/j.1527-2001.2006.tb00960.x

Kukla, R. (2006b). Ethics and ideology in breastfeeding advocacy campaigns. Hypatia, 21(1), pp. 157-180. http://dx.doi.org/10.1111/j.1527-2001.2006.tb00970.x

Mabilia, M. (2005). Breastfeeding and sexuality: Behaviour, beliefs and taboos among the Gogo mothers in Tanzania. Oxford: Berghahn Books.

MacGregor, B. \& Morrison, D. (1995). From focus groups to editing groups: A new method of reception analysis. Media, Culture and Society, 17(1), pp. 141-150. http://dx.doi.org/10.1177/016344395017001009

Maclean, H. (1990). Women's experience of breastfeeding. Toronto: University of Toronto Press.

Marshall, J. \& Godfrey, M. (2011). Shifting identities: Social and cultural factors that shape decision-making around sustaining breastfeeding. In Liamputtong, P. (ed). Infant Feeding Practices: A Cross-Cultural Perspective. New York: Springer. http://dx.doi.org/10.1007/978-1-4419-6873-9_6

Murphy, E. (1999). Breast is best: Infant feeding decisions and maternal deviance. Sociology of Health \& Illness, 2(2), pp. 187-208. http://dx.doi.org/10.1111/1467-9566.00149

Murphy, E. (2000). Risk, responsibility and rhetoric in infant feeding. Journal of Contemporary Ethnography, 29(291), pp. 391-324.

Philo, G. (1990). Seeing and believing: The influence of television. London: Routledge. http://dx.doi.org/10.4324/9780203326251

Silverman, D. (2001). Interpreting qualitative data: Methods for analysing talk, text and interaction (2nd ed). London: Sage. 
Table 1. Distribution of Focus Group Respondents

\begin{tabular}{|c|c|c|c|c|c|c|}
\hline $\begin{array}{l}\text { Focus } \\
\text { Group }\end{array}$ & Location & $\begin{array}{c}\text { Social / Occupational } \\
\text { Background }\end{array}$ & Name, & $\begin{array}{l}\text { cur } \\
\text { cho }\end{array}$ & nt feeding & $\begin{array}{c}\text { Total } \\
\text { participants } \\
\end{array}$ \\
\hline $\begin{array}{l}\text { Focus } \\
\text { Group } 1\end{array}$ & $\begin{array}{l}\text { Selangor } \\
\text { (City) }\end{array}$ & $\begin{array}{l}\text { Young Professionals } \\
\text { with Bachelor degree } \\
\text { Qualification }\end{array}$ & $\begin{array}{l}\text { Qaseh } \\
\text { Rania } \\
\text { Hannah } \\
\text { Mila }\end{array}$ & $\begin{array}{l}29 \\
29 \\
29 \\
29\end{array}$ & $\begin{array}{l}\mathrm{BF} \\
\mathrm{BF} \\
\mathrm{BF} \\
\mathrm{FF}\end{array}$ & 4 \\
\hline $\begin{array}{l}\text { Focus } \\
\text { Group } 2\end{array}$ & $\begin{array}{l}\text { Johor } \\
\text { (City) }\end{array}$ & $\begin{array}{l}\text { Working class family - } \\
\text { Stay at home moms and } \\
\text { working mothers with } \\
\text { High School / College } \\
\text { Qualification }\end{array}$ & $\begin{array}{l}\text { Mimi } \\
\text { Julita } \\
\text { Dina } \\
\text { Zaqyah } \\
\text { Lana }\end{array}$ & $\begin{array}{l}38 \\
39 \\
34 \\
34 \\
33\end{array}$ & $\begin{array}{l}\text { BF } \\
\text { FF } \\
\text { BF } \\
\text { NF } \\
\text { FF }\end{array}$ & 5 \\
\hline $\begin{array}{l}\text { Focus } \\
\text { Group } 3\end{array}$ & $\begin{array}{l}\text { Selangor } \\
\text { (City) }\end{array}$ & $\begin{array}{l}\text { Young professionals } \\
\text { working at a local } \\
\text { university }\end{array}$ & $\begin{array}{l}\text { Lina } \\
\text { Sarah } \\
\text { Zahra } \\
\text { Joyah }\end{array}$ & $\begin{array}{l}29 \\
29 \\
37 \\
29\end{array}$ & $\begin{array}{l}\mathrm{MF} \\
\mathrm{FF} \\
\mathrm{BF} \\
\mathrm{FF}\end{array}$ & 4 \\
\hline $\begin{array}{l}\text { Focus } \\
\text { Group } 4\end{array}$ & $\begin{array}{l}\text { Perak } \\
\text { (Town) }\end{array}$ & $\begin{array}{l}\text { Young administrative } \\
\text { staff working at a } \\
\text { teacher's college }\end{array}$ & $\begin{array}{l}\text { Nani } \\
\text { Cinta } \\
\text { Damia } \\
\text { Acha }\end{array}$ & $\begin{array}{l}29 \\
30 \\
31 \\
26\end{array}$ & $\begin{array}{l}\mathrm{FF} \\
\mathrm{BF} \\
\mathrm{BF} \\
\mathrm{BF}\end{array}$ & 4 \\
\hline $\begin{array}{l}\text { Focus } \\
\text { Group } 5\end{array}$ & $\begin{array}{l}\text { Pahang } \\
\text { (Town) }\end{array}$ & $\begin{array}{l}\text { Working class family. } \\
\text { Stay at home moms and } \\
\text { working moms, some } \\
\text { with university degree } \\
\text { qualifications }\end{array}$ & $\begin{array}{l}\text { Khayra } \\
\text { Kimie } \\
\text { Bedah } \\
\text { Layla } \\
\text { Marissa } \\
\text { Yasmin }\end{array}$ & $\begin{array}{l}33 \\
29 \\
29 \\
24 \\
29 \\
33\end{array}$ & $\begin{array}{l}\text { MF } \\
\text { FF } \\
\text { FF } \\
\text { FF } \\
\text { FF } \\
\text { FF }\end{array}$ & 6 \\
\hline $\begin{array}{l}\text { Focus } \\
\text { Group } 6\end{array}$ & $\begin{array}{l}\text { Perak } \\
\text { (Rural) }\end{array}$ & $\begin{array}{l}\text { Working moms at two } \\
\text { local university state } \\
\text { branches. All with } \\
\text { University degree } \\
\text { qualifications } \\
\end{array}$ & $\begin{array}{l}\text { Naema } \\
\text { Aminah } \\
\text { Verra } \\
\text { Damia }\end{array}$ & $\begin{array}{l}35 \\
29 \\
29 \\
31\end{array}$ & $\begin{array}{l}\mathrm{FF} \\
\mathrm{BF} \\
\mathrm{MF} \\
\mathrm{MF}\end{array}$ & 4 \\
\hline $\begin{array}{l}\text { Focus } \\
\text { Group } 7\end{array}$ & $\begin{array}{l}\text { Kuala } \\
\text { Lumpur } \\
\text { (City) }\end{array}$ & $\begin{array}{l}\text { Working moms with } \\
\text { university degree } \\
\text { qualifications }\end{array}$ & $\begin{array}{l}\text { Rabiah } \\
\text { Iza } \\
\text { Maria }\end{array}$ & $\begin{array}{l}29 \\
29 \\
29\end{array}$ & $\begin{array}{l}\text { MF } \\
\text { FF } \\
\text { BF }\end{array}$ & 3 \\
\hline $\begin{array}{l}\text { Focus } \\
\text { Group } 8\end{array}$ & $\begin{array}{l}\text { Selangor } \\
\text { (City) }\end{array}$ & $\begin{array}{l}\text { Working Class Family - } \\
\text { Stay at home moms/ } \\
\text { teachers/working moms, } \\
\text { some with university } \\
\text { degree qualification }\end{array}$ & $\begin{array}{l}\text { Sofea } \\
\text { Latifah } \\
\text { Heidi } \\
\text { Lola } \\
\text { Tina } \\
\text { Orked }\end{array}$ & $\begin{array}{l}40 \\
28 \\
27 \\
41 \\
37 \\
34\end{array}$ & $\begin{array}{l}\mathrm{FF} \\
\mathrm{FF} \\
\mathrm{FF} \\
\mathrm{FF} \\
\mathrm{BF} \\
\mathrm{NF}\end{array}$ & 6 \\
\hline $\begin{array}{l}\text { Focus } \\
\text { Group } 9\end{array}$ & $\begin{array}{l}\text { Kelantan } \\
\text { (Rural) }\end{array}$ & $\begin{array}{l}\text { Stay at home moms with } \\
\text { low income family }\end{array}$ & $\begin{array}{l}\text { Mas } \\
\text { Yusra } \\
\text { Bunga } \\
\text { Fatima } \\
\end{array}$ & $\begin{array}{l}24 \\
38 \\
24 \\
39 \\
\end{array}$ & $\begin{array}{l}\text { MF } \\
\text { MF } \\
\text { MF } \\
\text { MF }\end{array}$ & 4 \\
\hline
\end{tabular}




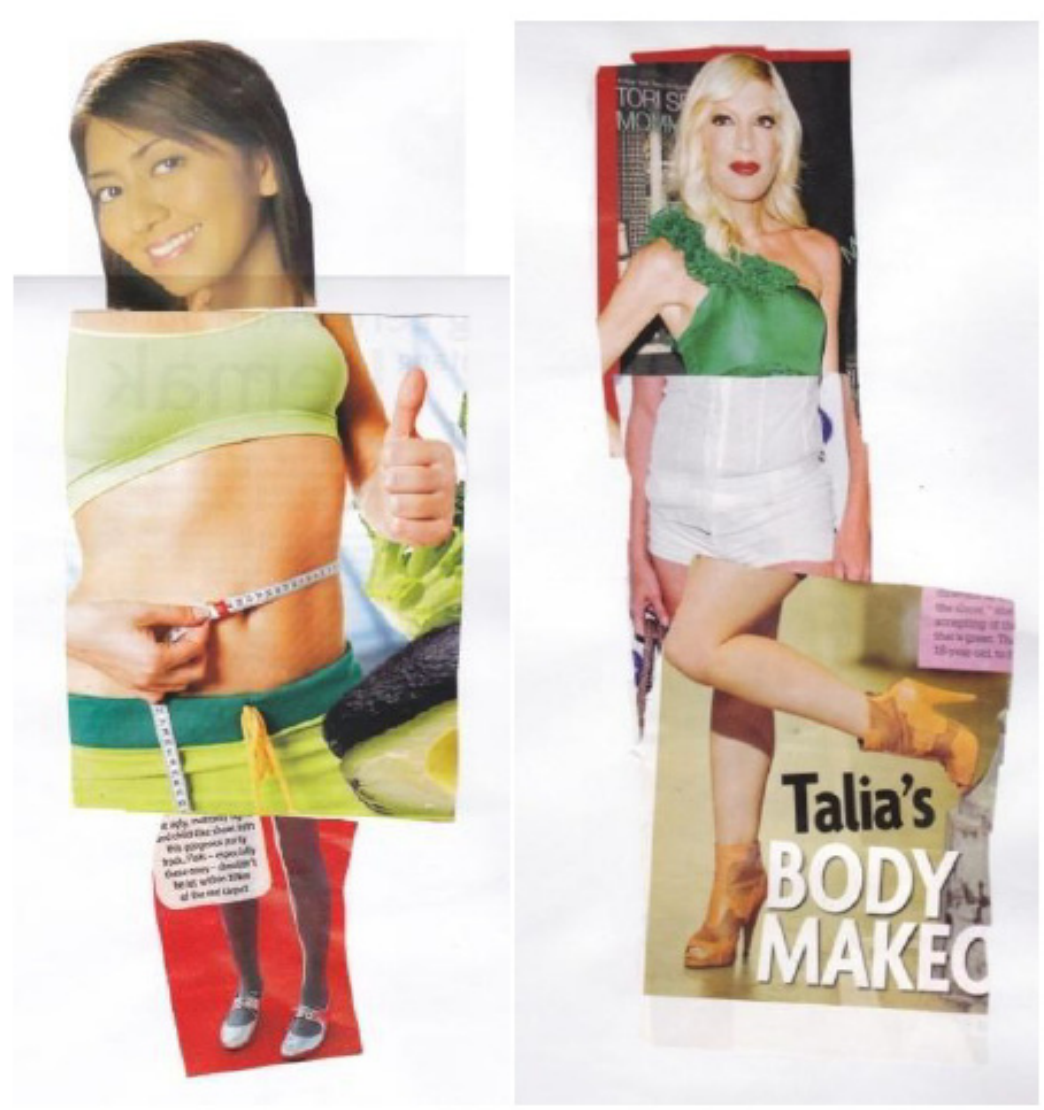

Figure 1. Example of healthy breastfeeding woman (left) vs. unhealthy formula feeding woman (right) by Group 1, Focus Group 7

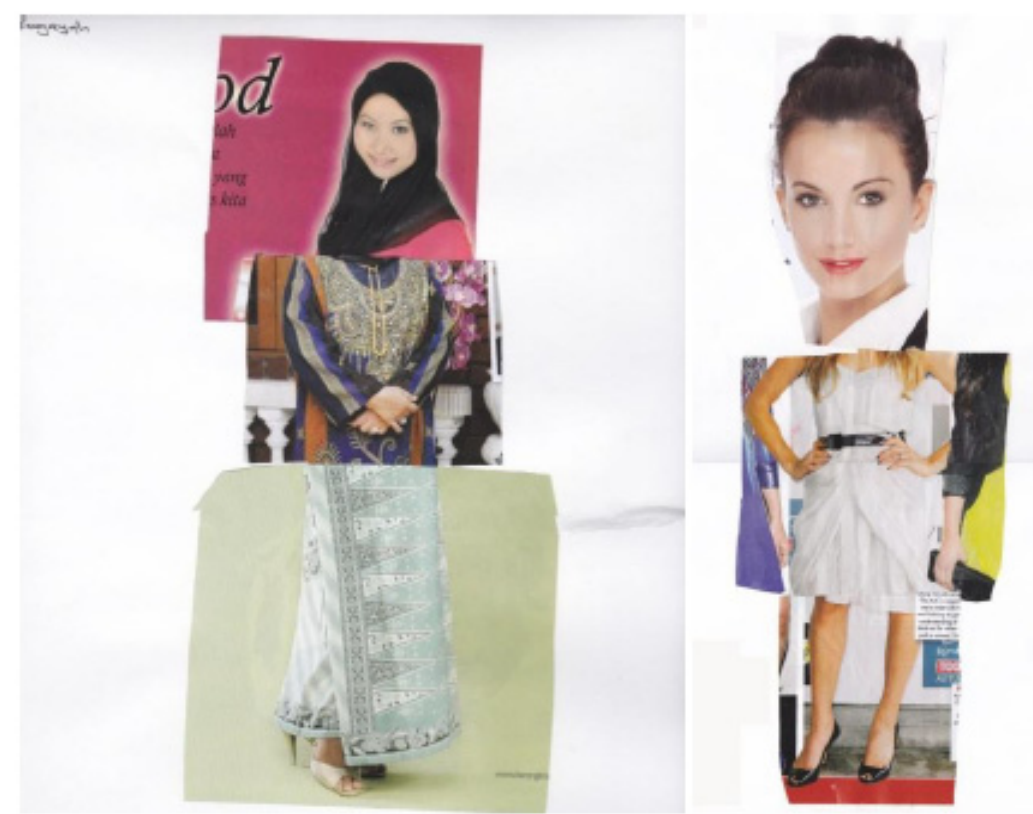

Figure 2. An example of traditional look for Malay breastfeeding woman (left) vs. Modern look for formula feeding Malay woman (right) constructed by Group 1, Focus Group 9 

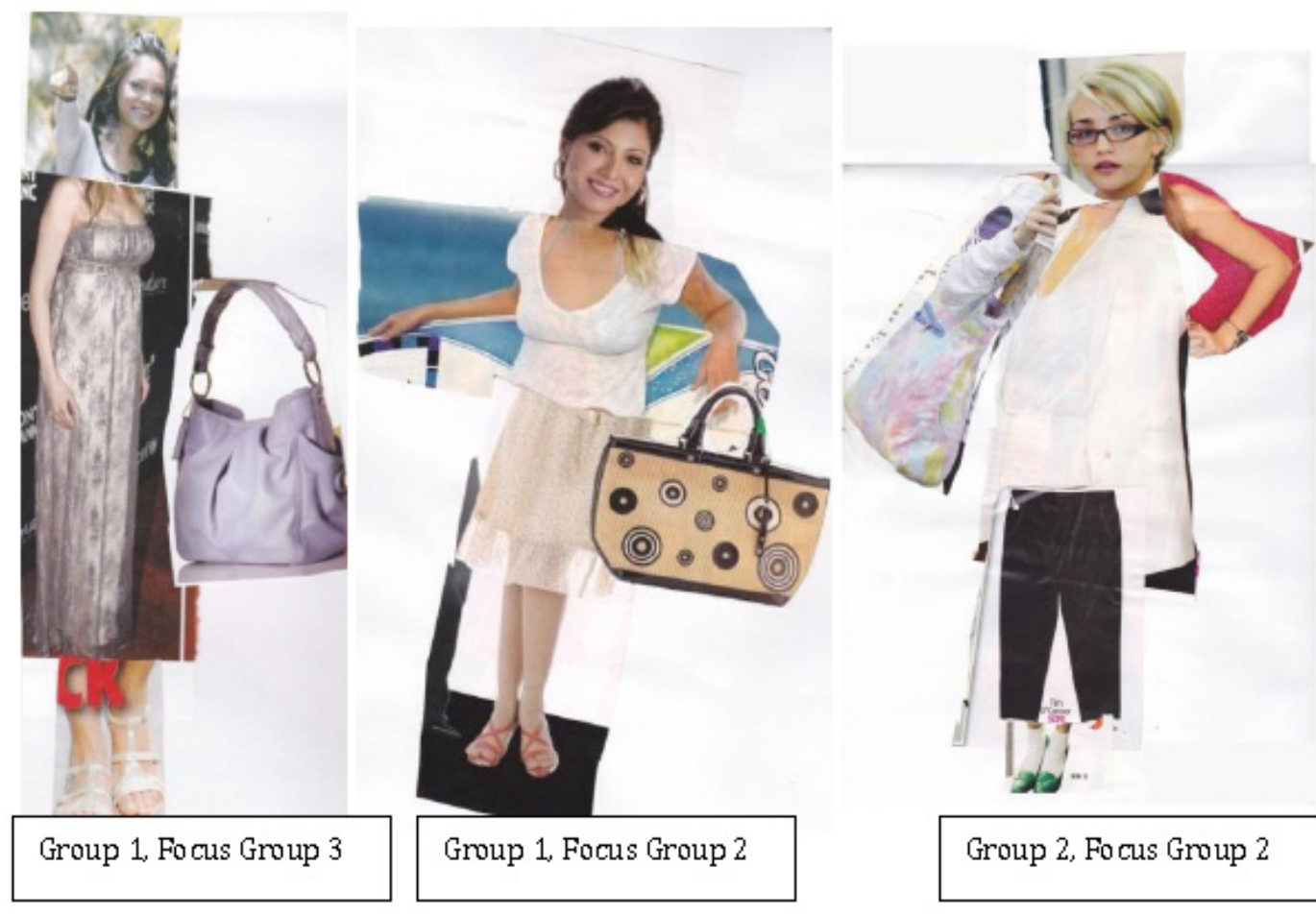

Group 1, Focus Group 3

Figure 3. Example of breastfeeding collages - Large bags and flat shoes
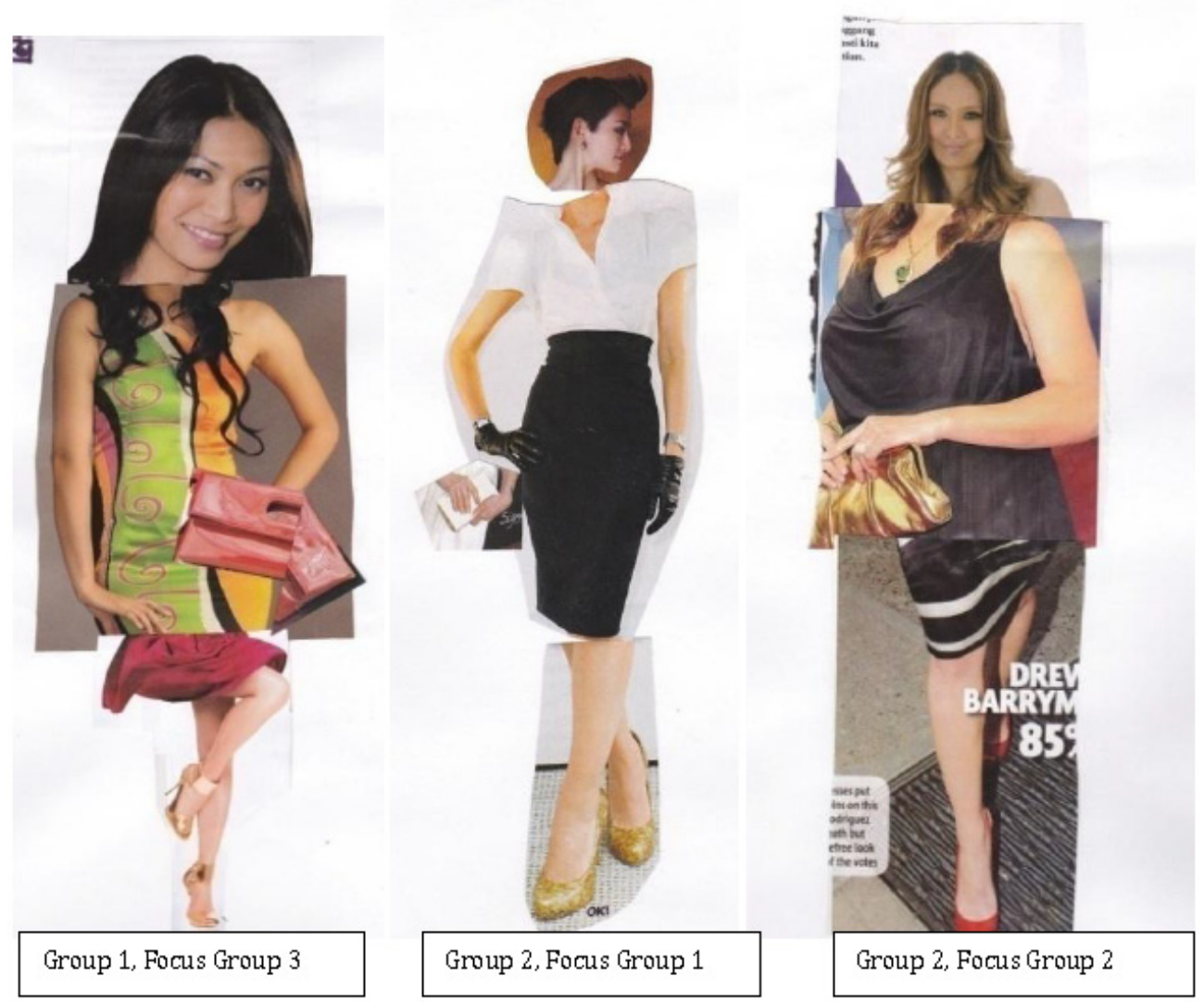

Figure 4. Examples of formula feeding collages - Small bags and high heels 


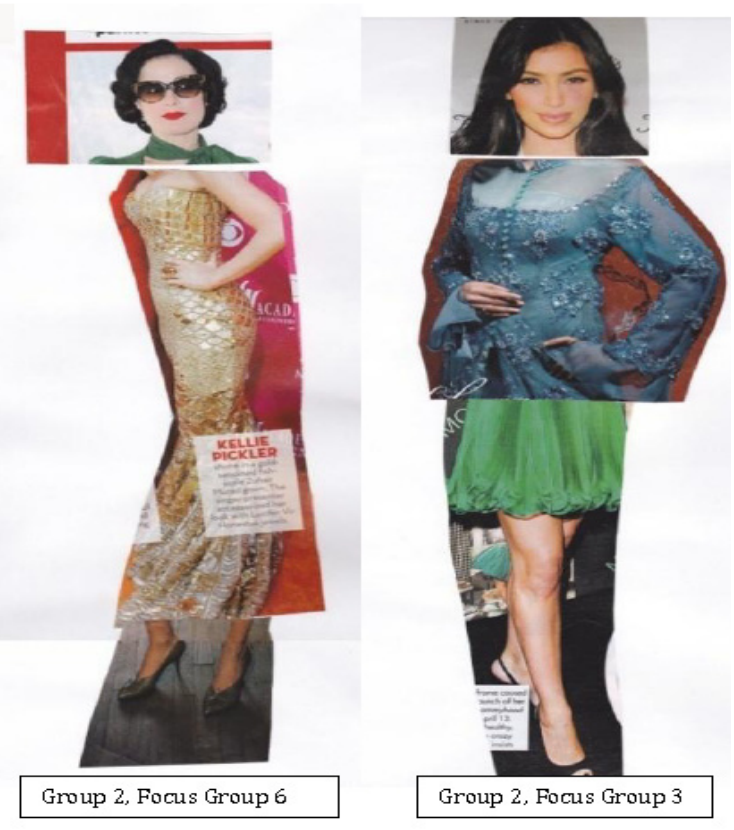

Figure 5. Examples of collages of formula feeding collages - Sexy hourglass bodies and tight fitting clothes

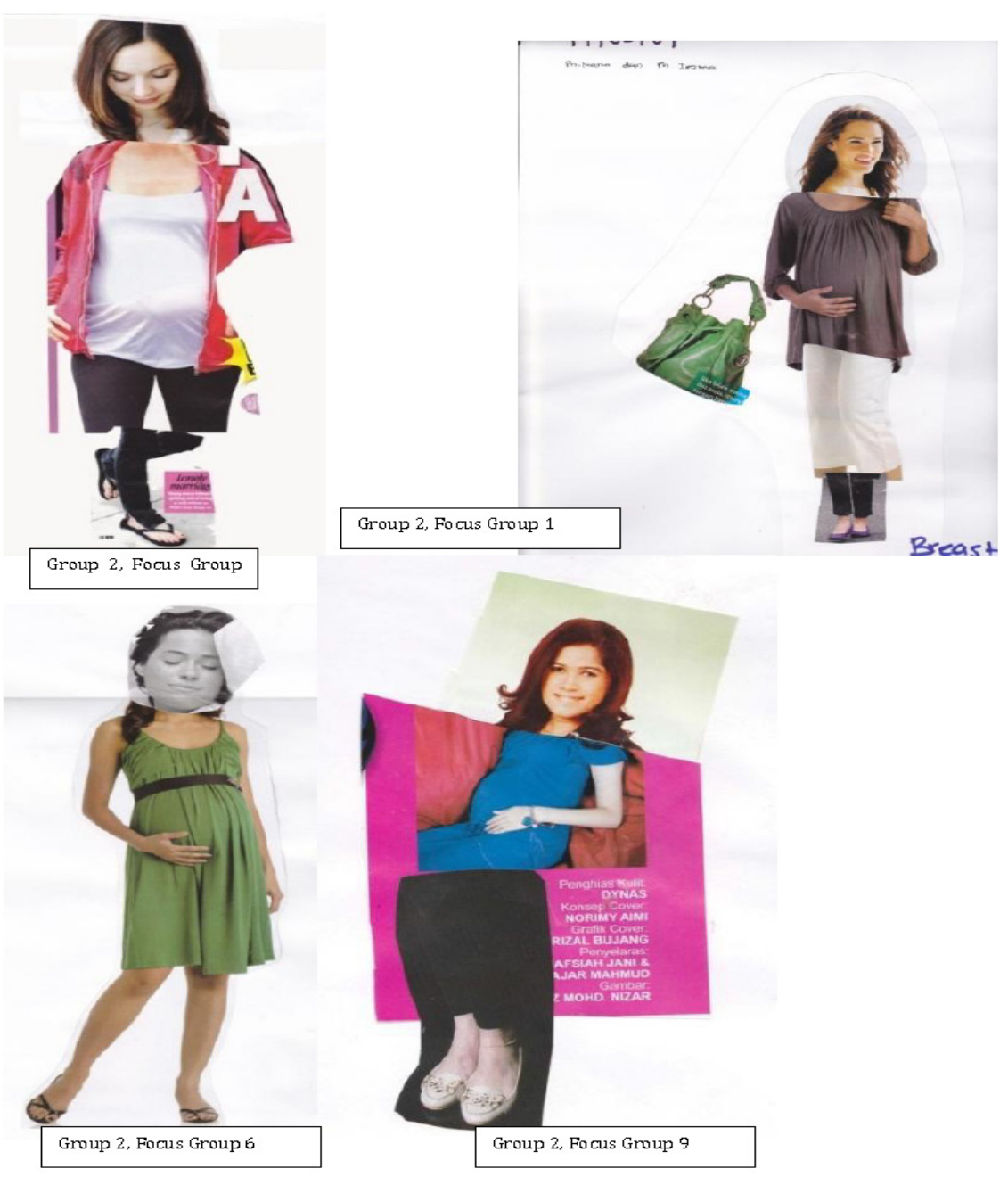

Figure 6. Examples of breastfeeding collages - Pregnant bodies 

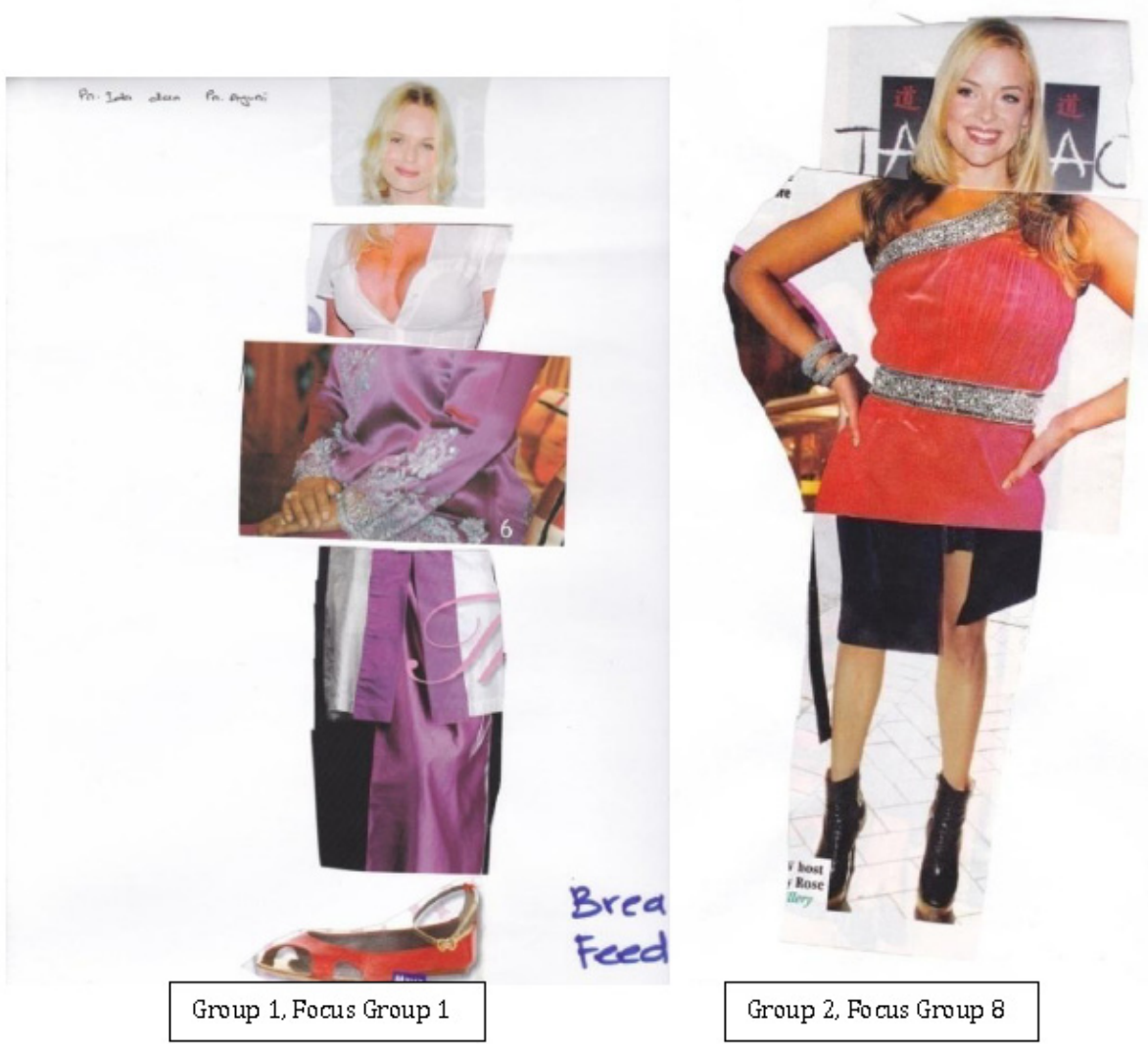

Figure 7. Examples of Big Breasts - Breastfeeding collage (left) and Formula Feeding collage (right)
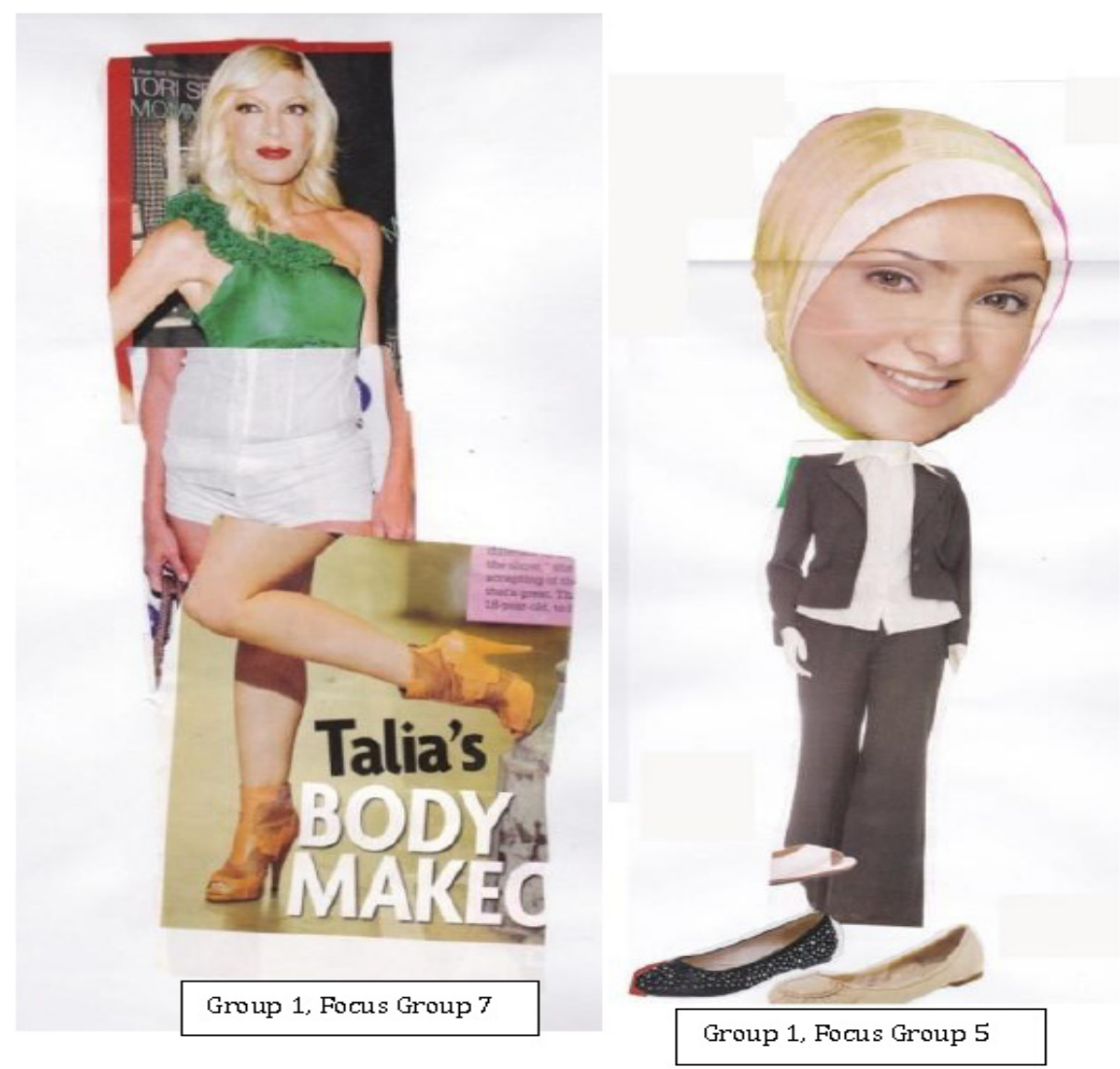

Figure 8. Western vs. hijabi/Malay looking women - Examples of formula feeding (left) and breastfeeding (right) collages 

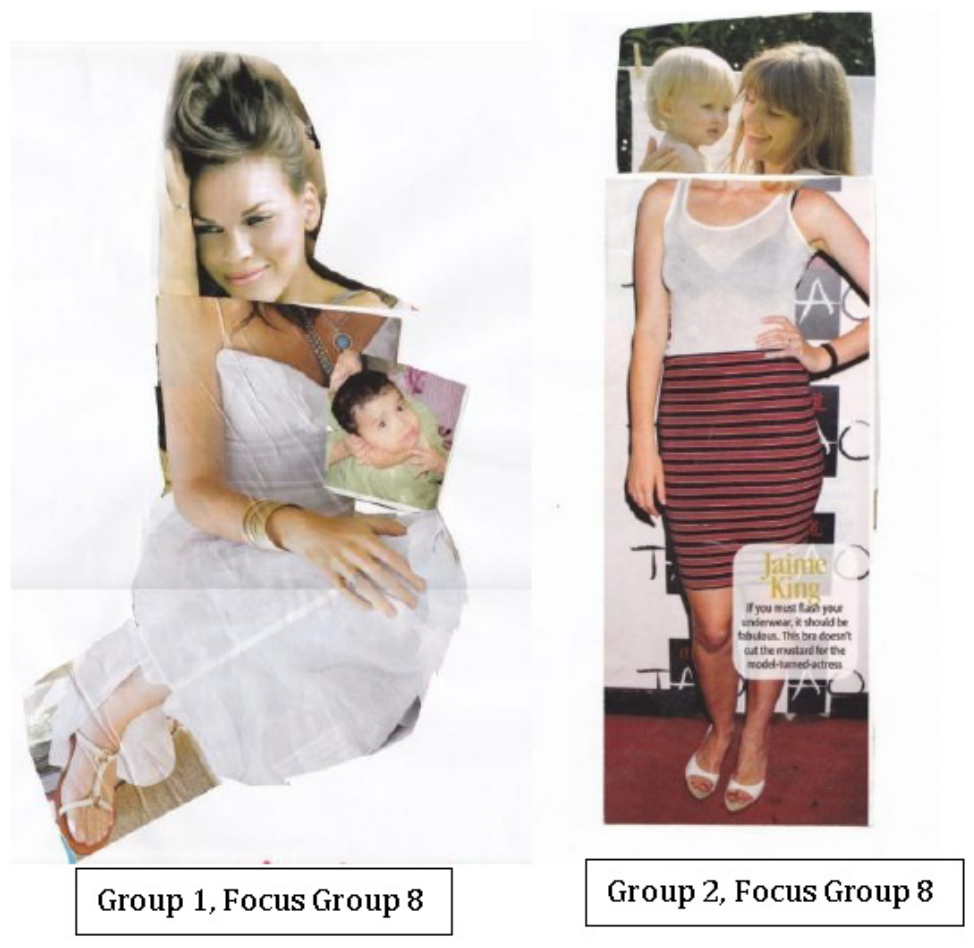

Figure 9. Breastfeeding collages showing mother and baby

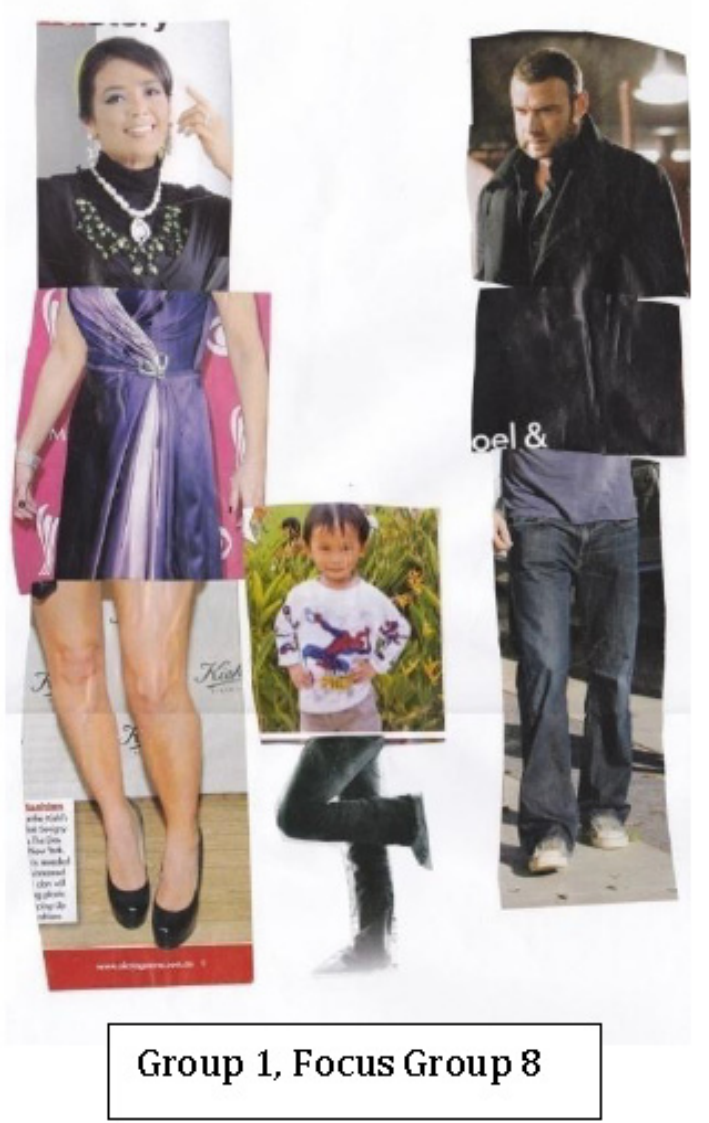

Figure 10. A Formula feeding collage including a child and a father figure 